\section{z Filologii Polskiej i Słowiańskiej}

DOI: $10.11649 /$ sfps.1673
Article No. 1673

\section{Citation:}

Kiklewicz, A. (2019). Formy reprezentacji argumentu propozycjonalnego w bułgarskich, polskich i rosyjskich zdaniach ufundowanych na predykacie mentalnym. Studia $z$ Filologii Polskiej i Słowiańskiej, 54. https://doi.org/10.11649/sfps.1673

\author{
Aleksander Kiklewicz \\ (Uniwersytet Warmińsko-Mazurski w Olsztynie)
}

\title{
Formy reprezentacji argumentu propozycjonalnego w bułgarskich, polskich i rosyjskich zdaniach ufundowanych na predykacie mentalnym
}

1.

Czasowniki mentalne tworzą klasę jednostek leksykalnych, którym z syntaktycznego punktu widzenia - przysługuje funkcja predykatów drugiego rzędu, tzn. takich, które wymagają obecności przynajmniej jednego argumentu propozycjonalnego (dalej: AP), będącego nazwą sytuacji, zdarzenia, procesu lub stanu. W językach słowiańskich zachodzi duże podobieństwo tych czasowników pod względem właściwości propozycjonalno-semantycznych. Formy reprezentacji argumentów propozycjonalnych także są przeważnie te same, jednak, jak wykazuje pobieżne porównanie faktów językowych, często różnią się one w aspekcie funkcjonalnym - dotyczy to np. częstości używania oraz nacechowania stylistycznego (stosunku do normy ogólnej lub wzorcowej). Badanie trzech języków słowiańskich - bułgarskiego, polskiego i rosyjskiego, reprezentujących języki południowo-, zachodnio- i wschodniosłowiańskie -

This is an Open Access article distributed under the terms of the Creative Commons Attribution 3.0 PL License (creativecommons.org/licenses/by/3.0/pl/), which permits redistribution, commercial and non-commercial, provided that the article is properly cited. (c) The Author(s) 2019.

Publisher: Institute of Slavic Studies, Polish Academy of Sciences

[Wydawca: Instytut Slawistyki Polskiej Akademii Nauk] 
w perspektywie porównawczej stanowi przedmiot tego artykułu. Za narzędzia badawcze posłużą kategorie składni eksplikacyjnej - kierunku wiedzy lingwistycznej, u podstaw którego leży teoria składni semantycznej Stanisława Karolaka (Karolak, 1984, 2002), zastosowana w publikacjach przedstawicieli tzw. polskiej szkoły składni semantycznej (Kiklewicz, 2009, 2014, 2017d, 2017e; Киклевич, 2015, 2016a, 2016b; Kiklewicz \& Korytkowska, 2010, 2012, 2013; Киклевич \& Корытковская, 2012; Kokot-Góra, 2015a, 2015b; Korytkowska, 1992, 2013, 2014, 2017a, 2017b; Korytkowska \& Kiklewicz, 2013, 2016; Korytkowska \& Mazurkiewicz-Sułkowska, 2014; Mazurkiewicz-Sułkowska, 2016; Papierz, 2013; Szumska, 2017 i in.). Materiał empiryczny został zebrany i opracowany w trakcie realizacji projektu naukowo-badawczego „Właściwości składniowe czasowników jako baza ich zintegrowanego opisu leksykograficznego (w perspektywie konfrontacji polsko-bułgarsko-rosyjskiej)" realizowanego w latach 2014-2017 przy wsparciu finansowym Narodowego Centrum Nauki. W realizacji projektu brały udział (poza autorem tego artykułu) Małgorzata Korytkowska, Julia Mazurkiewicz-Sułkowska i Agnieszka Zatorska.

\section{2.}

Zgodnie z założeniami składni eksplikacyjnej konstrukcje składniowe (o cechach formalno-gramatycznych czy też morfosyntaktycznych) są ufundowane na walencji składnika głównego, konotującego. W tym przypadku chodzi o wymagania pozycyjne czasownika mentalnego w pozycji orzeczenia. Specyfika predykatów mentalnych ${ }^{1}$ (niezależnie od formy ich gramatycznej reprezentacji) polega na tym, że pierwsza pozycja przysługuje argumentowi o znaczeniu experiencera, czyli podmiotu czynności mentalnej lub stanu, procesu mentalnego, a druga pozycja - AP o znaczeniu przedmiotu myśli, poznania, wiedzy ${ }^{2}$. Struktura propozycjonalna typu $P(x, q)$ jest najczęściej reprezentowana $\mathrm{w}$ każdym $\mathrm{z}$ badanych języków słowiańskich: $\mathrm{w}$ języku bułgarskim przypada na nią 82,5\% czasowników, w języku polskim - 76,7\% czasowników, a w języku rosyjskim - 84\% czasowników.

1 Właściwości jednostek tej klasy leksykalno-semantycznej zostały opisane w publikacjach: Kiklewicz, 2017b, 2017c.

${ }^{2}$ We wszystkich badanych językach występuje także nieduża liczba predykatów trzymiejscowych, implikujących dwa argumenty przedmiotowe lub dwa argumenty propozycjonalne. 
Można wyodrębnić następujące typy realizacji AP (o tym zob. także: Kiklewicz, 2017a, s. 80):

1. przestrzeganie ${ }^{3}$ - dyskretna (czyli izosemiczna, kompletna) realizacja AP $\mathrm{w}$ formie aktanta sentencjonalnego (zdania zależnego); symbolicznie $\mathrm{AP} \rightarrow S_{q}$;

2. kompresja/kondensacja:

2.1. realizacja AP w formie leksykalnego wykładnika (grupy imiennej lub bezokolicznika) predykatu propozycji zależnej (w przypadku realizacji wpół dyskretnej); symbolicznie AP $\rightarrow N V_{q} \ldots, \mathrm{AP} \rightarrow V I_{q} \ldots$;

2.2. realizacja $\mathrm{AP} w$ formie grupy imiennej będącej wykładnikiem argumentu propozycji zależnej (w przypadku realizacji niedyskretnej); symbolicznie $\mathrm{AP} \rightarrow N V_{a q} \varnothing_{q}$ lub $\mathrm{AP} \rightarrow N_{a q} \varnothing_{q}$;

3. wyzerowanie (kontekstowe lub bezkontekstowe) - brak wypełnienia pozycji AP; symbolicznie AP $\rightarrow \varnothing_{q}$;

4. rozszczepienie - realizacja AP w postaci dwóch aktantów (zwykle dwóch grup imiennych) reprezentujących elementy propozycji zależnej; symbolicznie AP $\rightarrow N V_{q} \ldots N V_{a q}$, AP $\rightarrow N_{a q} N_{a q} \varnothing_{q}, \mathrm{AP} \rightarrow N_{a q} N V_{P q} \varnothing_{V q}$ i in.

W kolejnych punktach rozważę wymienione typy realizacji AP w badanych językach słowiańskich.

\section{1.}

Schematy eksplikacyjne, w których AP został wyrażony w formie zdania zależnego, stanowią typ gramatycznej strukturalizacji zdania opartej na przestrzeganiu: struktura formalno-gramatyczna jest kompatybilna ze strukturą semantyczną:

$$
P(x, q) \rightarrow V N_{x} S_{q}
$$

Poniżej przytoczono przykłady zdań realizujących takie formy syntaktyczne w trzech językach:

\section{JĘZYK BUŁGARSKI:}

[Тогава] замислих (това), как да започна да произвеждам подови настилки.

Тя калкулира как тези преговори ще се отразяват на имиджа на партията й.

3 Termin został zapożyczony z koncepcji składni dynamicznej B. J. Normana (Норман, 1994, s. 176); w wersji rosyjskiej brzmi соблюдение. 
Сега уча (това), че партизантите се криели по селата.

Той сбърка това, което иска с онова, от което всъщност се нуждае.

JĘZYK POLSKI:

Myślę, że należy tak postąpić / że Piotr postąpił dobrze.

Gabryś rozmarzył się (nad tym), co się będzie działo.

Adam wspominał, że podczas wyjazdu na Bali było pięknie.

To, że nie udzieli nam głosu, prowadząca spotkanie umotywowała tym, że burmistrz tego zabronił.

\section{JEZYK ROSYJSKI:}

Он сходу уразумел, насколько в его хозяйстве может быть полезным этот немец. Затем композитор додумался, что длиться песня будет тоже пять минут.

Я запрограммировал, куда по этой тропинке что расставить.

Я представил, что в том мире воздух был вот такой, неплотный.

Mimo że ta forma realizacji AP ma najbardziej kompletny charakter, adekwatny do struktury propozycjonalno-semantycznej zdania, nie wszystkie czasowniki dopuszczają obecność aktanta sentencjonalnego. Na przykład polski czasownik uogólniać/uogólnić realizuje strukturę propozycjonalną $P(x, q)$, ale w pozycji $q$ występuje odczasownikowy derywat $\left(N V_{q}\right.$ lub $\left.N V_{a q}\right)$ albo zero syntaktyczne:

Kwaśniewski uogólnia zarzuty.

Pisarz uogólnił swój pogląd na świat.

Człowiek często uogólnia swoje doświadczenia/doświadczenie.

Ten nauczyciel [często] ${ }^{4}$ uogólnia.

[Nie mam do niego zaufania] - on [często bezpodstawnie] uogólnia.

Aktant sentencjonalny jest blokowany za sprawą czynników semantycznych. Dotyczy to niektórych czasowników mentalnych o charakterze pochodnym, tzn. powstałych na skutek derywacji semantycznej, czyli metaforycznego użycia czasowników o znaczeniu czynności fizycznej. Znaczenie podstawowe takich wyrazów jak:

bułg. задълбочавам се / задълбоча се, вглъбявам се / вглъбя се

pol. wgłębiać się / wgłębić się, zagłębiać się / zagłębić się

ros. проникать/проникнуть, углубляться/углубиться

nie zostało prawdopodobnie całkowicie zdezaktualizowane i ta swoista „pamięć” derywacyjna uniemożliwia konstrukcję zdania złożonego.

${ }^{4}$ Nawiasy kwadratowe [...] wskazują na składniki syntaktyczne fakultatywne z punktu widzenia wymogów walencyjnych czasownika osobowego. 
Aktant sentencjonalny nie jest dopuszczalny także w zdaniach z czasownikami o znaczeniu zamiaru:

pol. myśleć 3 , zamierzać/zamierzyć

ros. думать 3 , намереваться/намериться, собираться/собраться

Czasowniki te nazywają stan myślowy człowieka, który chce coś osiągnąć i jest gotów dołożyć starań, żeby tak się stało (zob. Апресян, 2004, s. 587). Najczęściej w pozycji drugiego argumentu przy takich czasownikach występuje infinityw. Nie dotyczy to jednak języka bułgarskiego, w którym czasowniki възнамерявам/

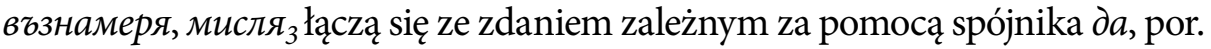

Възнамерих да участвам в коледния конкурс.

Възнамерихме да сторим нещо лошо.

Аз мисля пък да и взема 10 чифта очила.

Мисля да пътувам.

Można to tłumaczyć specyfiką bułgarskich $\partial a$-konstrukcji, o których badacze piszą, że mają niezupełnie określony status, gdyż wykazują właściwości zarówno zdania zależnego, jak i orzeczenia modalnego (zob. Викторова, 2005, s. 223; Иванова, 2014, s. 111). Nadieżda. Kotowa i Mirosław. Janakijew (Котова \& Янакиев, 2001, s. 732) konstatują, że w języku rosyjskim da-konstrukcjom odpowiadają konstrukcje bezokolicznikowe.

Tabela 1. zawiera wykaz czasowników trzech badanych języków, które nie dopuszczają aktanta sentencjonalnego w pozycji AP.

Analiza ilościowa materiału źródłowego wykazała, że regularność występowania aktanta sentencjonalnego jako elementu walencji czasowników mentalnych w różnych językach jest odmienna: w języku bułgarskim takie jednostki obejmują $6,2 \%$ czasowników mentalnych, w języku polskim - 7,6\%, a w języku rosyjskim - 9,5\%. Jak widać, najbardziej regularnie aktant sentencjonalny jest realizowany w rosyjskim, a najmniej regularnie - w bułgarskim, mimo występowania w nim semantycznie pojemnych i ambiwalentnych $\partial a$-konstrukcji.

Należy też zaznaczyć, że nie wszystkie odpowiedniki leksykalne mają w trzech językach jednakowe cechy walencyjne (co m.in. dotyczy dopuszczalności lub niedopuszczalności aktanta sentencjonalnego). Można na tej podstawie wnioskować, że cechy semantyczne jednostek, decydujące o ich przynależności do określonych klas taksonomicznych, niezupełnie warunkują ich właściwości kombinatoryczne, na które wpływa ponadto znaczenie gramatyczne, a także to, co Ferdinand de Saussure (de Saussure, 2002, s. 104) określał jako value, 
czyli miejsce jednostki w systemie leksykalnym języka (przy uwzględnieniu relewantnych opozycji z udziałem wszystkich jednostek).

Tabela 1. Czasowniki niedopuszczające realizacji AP w formie aktanta sentencjonalnego

\begin{tabular}{|c|c|c|}
\hline Język bułgarski & Język polski & Język rosyjski \\
\hline $\begin{array}{l}\text { зубря } \\
\text { изпонаизмислям/ } \\
\text { изпоизмисля } \\
\text { изпонарешавам/ } \\
\text { изпонареша } \\
\text { категоризирам } \\
\text { класифицирам } 1 \\
\text { лутам се } \\
\text { медитирам } \\
\text { наизмислям/наизмисля } \\
\text { научавам } / \text { /науча } 1 \\
\text { овладявам/овладея } \\
\text { озарявам/озаря } \\
\text { отвличам се/ отвлека се } \\
\text { попреценявам/попреценя } \\
\text { разрешавам/разреша } \\
\text { сбърквам } / \text { сбъркам } \\
\text { съчинявам/съчиня }\end{array}$ & $\begin{array}{l}\text { klasyfikować }_{1} \\
\text { klasyfikować } \\
\text { kwalifikować } \\
\text { mylić } \\
\text { myślećć }_{3} \\
\text { pokontemplować } \\
\text { pomieszać } \\
\text { pooceniać } \\
\text { porozstrzygać } \\
\text { powymyślać } \\
\text { rozmyślać się / rozmyślić się } \\
\text { rozróżniać/rozróżnić } \\
\text { sklasyfikować } \\
\text { sklasyfikować } \\
\text { uogólniać/uogólnić } \\
\text { wynajdować/wynaleźć } \\
\text { zakwalifikować } \\
\text { zamierzać/zamierzyć } \\
\text { znać }\end{array}$ & 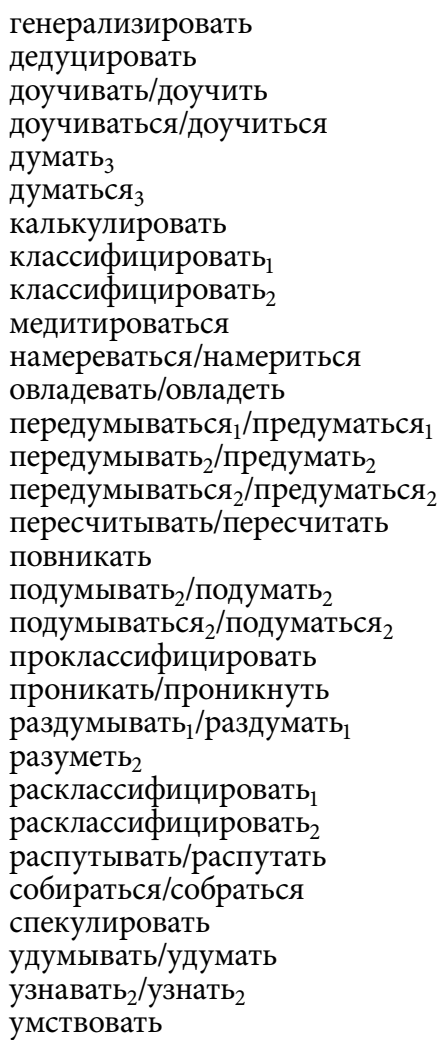 \\
\hline
\end{tabular}

Kompresja formy realizacji AP występuje, jak już zaznaczono, w kilku odmianach, w zależności od stopnia dekonstrukcji zdania zależnego jako podstawowej formy. Za wpół dyskretne uznawane są takie schematy eksplikacyjne, w których propozycja zależna jest reprezentowana $\mathrm{w}$ formie grupy imiennej, semantycznie równoważnej z zależnym predykatem. Takie formy syntaktyczne kwalifikuje się za pomocą symboli $N V_{p}, N V_{q}, N V_{r}$ Na przykład w polskim zdaniu: 
Placówki naukowe upewniły się w finansowaniu jednostek $\mathrm{z}$ funduszy ministerialnych.

występuje rzeczownik dewerbatywny finansowanie będący rezultatem nominalizacji predykatu propozycji zależnej, na co wskazuje poniższa transformacja:

$\ldots<$ Placówki naukowe upewniły się w tym, że jednostki zostaną sfinansowane / będą finansowane $\mathrm{z}$ funduszy ministerialnych.

Ufundowana na rzeczowniku abstrakcyjnym (zwykle dewerbatywnym) grupa imienna jest najbardziej regularną formą realizacji AP we wszystkich trzech językach, przy tym w języku bułgarskim jest ona dopuszczalna w przypadku 98,1\% czasowników, w języku polskim - 98,4\% czasowników, a w języku rosyjskim - 95,1\% czasowników. Istnieją tylko nieliczne jednostki leksykalne, które nie dopuszczają takiej formy gramatycznej w pozycji AP (zob. poniższą tabelę).

Tabela 2. Czasowniki niedopuszczające realizacji AP w formie rzeczownika dewerbatywnego

\begin{tabular}{|c|c|c|}
\hline Język bułgarski & Język polski & Język rosyjski \\
\hline $\begin{array}{l}\text { вярвам } 2 \\
\text { доучавам се / доуча се } \\
\text { мисля } 1 \\
\text { размислям } 2 / \text { размисли } 2 \\
\text { смятам/сметна }\end{array}$ & $\begin{array}{l}\text { oświecić } \\
\text { przypuszczać } \\
\text { uważać } \\
\text { wierzyćc }\end{array}$ & $\begin{array}{l}\text { верить }_{2} \\
\text { вздумать } \\
\text { думаться }_{2} \\
\text { думаться }_{3} \\
\text { задуматься }_{2} \\
\text { заколебаться } \\
\text { надуматься } \\
\text { намереваться } \\
\text { передумывать } / \text { передумать } 2 \\
\text { передумываться } / \text { передуматься } 2 \\
\text { подуматься } 2 \\
\text { признавать } \\
\text { раздумывать } 2 \\
\text { сдаваться/сдаться } \\
\text { собираться/собраться } \\
\text { удумывать/удумать }\end{array}$ \\
\hline
\end{tabular}

Ta grupa czasowników jest, jak widać, nieliczna, nie ma więc możliwości, żeby twierdzić o jakichkolwiek regularnych powiązaniach między walencją czasowników a ich charakterystyką semantyczną. Można jednak zauważyć (szczególnie na materiale języka rosyjskiego, w którym tych jednostek jest nieco więcej), że nominalizacji predykatu zależnego nie sprzyjają znaczenie zamiaru czasownika w pozycji orzeczenia, jak również konstrukcje diatezy pochodnej, najczęściej z czasownikiem zwrotnym w pozycji orzeczenia. Na przykład 


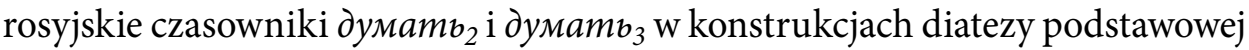
(aktywnej) dopuszczają $N V_{q}$ w pozycji drugiego argumentu:

Он думает 2 о войне как о проявлении безнравственности.

Он думает 2 о ее стараниях только хорошее.

Он правильно думает 2 о таких решениях.

Он правильно думает 2 о его приезде как попытке оказать на нас давление.

Он даже серьезно думает о $_{3}$ певческой карьере // о поступлении в академию.

Jednak ten rodzaj łączliwości składniowej nie jest dopuszczalny w przy-

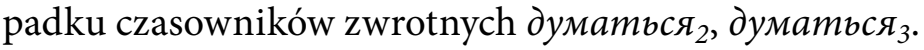

$\mathrm{W}$ języku polskim i rosyjskim predykat propozycji zależnej jest ponadto realizowany w formie bezokolicznika. Nie jest to regularna forma syntaktyczna: w języku polskim stanowi ona cechę walencyjną jedynie 13,3\% czasowników, a w języku rosyjskim - 13,9\% czasowników. Zwykle są to czasowniki wyrażające znaczenia zamiaru, planowania, przewidywania itp.

\section{3.}

Niedyskretne schematy eksplikacyjne powstają na skutek wyodrębnienia ze struktury AP jednego z argumentów, który zostaje wyrażony $\mathrm{w}$ formie grupy imiennej, zależnej od czasownika w pozycji orzeczenia (w zdaniu głównym). Ze względu na znaczenie takie grupy imienne występują w dwóch odmianach: substancjalne (AP $\rightarrow N_{a q} \varnothing_{q}$ ), np. stót, drzewo, gość, lalka itp., lub sentencjonalne (AP $\left.\rightarrow N V_{a q} \varnothing_{q}\right)$, np. wykład, ślub, koncert, raj, teoria, wiec itp. Poniżej przytoczono przykłady z trzech języków:

JĘZYK BUŁGARSKI:

Той анализира противниците ни.

Полицаят идентифицира жертвата.

Ония ден обърках жена си с крадец.

Не виждам никакъв смисъл в тази война.

JĘZYK POLSKI:

Adam lekceważy takich ludzi.

Anna wszystkich osądza.

Poznaliśmy wtedy [lepiej] naszego kolegę.

Prababka [kilka minut] powspominała odgłosy.

JĘZYK ROSYJSKI:

Писатель замышляет новую книгу.

Ему мнятся уже другие постели. 
Он проанализировал действующие центры обработки телефонных вызовов. Дедушку заинтриговали новые технологии в биржевой индустрии.

Często konstrukcje tego typu, szczególnie z $N_{a q}$, mają charakter potoczny, występują ponadto w tekstach stylów funkcjonalnych, naśladujących komunikację potoczną, tzn. artystycznych i publicystycznych. Potwierdzeniem tego są wybrane przykłady z języka rosyjskiego:

Иван вникает в бумаги.

«Харлей-дуралей» додумался до Синицына.

Он мудрит с веревками.

Мы на сегодня запланировали библиотеку.

Она рассчитывала на Ирину.

Na przykład w ostatnim zdaniu konstrukcja przyimkowo-rzeczownikowa (z rzeczownikiem w bierniku) reprezentuje AP, który da się zrekonstruować w oparciu o kontekst lub konsytuację, por.

... < Она рассчитывала на то, что Ирина ей поможет / поддержит ее / заступится за нее и т.д.

Konieczność odwołania się do kontekstu (czyli tzw. substancjalność), jak wiadomo, stanowi jedną z najważniejszych cech komunikacji potocznej (zob. Warchala, 2003, s. 40).

Szczególnego omówienia wymaga funkcjonalna ambiwalencja rzeczowników abstrakcyjnych (symbol $N V$ ), które, jak wynika z poprzednich punktów, mogą reprezentować znaczenie predykatu (por. wyrazy napisanie, powiedzenie, przyjście, wykonanie, realizacja i in.) lub znaczenie argumentu (por. wyrazy wykład, ślub, koncert, deklaracja, piekło, śniadanie i in.). Rozważmy w związku z tym dwa polskie zdania:

Historyk sztuki powątpiewa w odzyskanie XVI-wiecznego zamku obronnego.

Lekarz powątpiewa o ciąży.

W pierwszym zdaniu rzeczownik odzyskanie reprezentuje predykat propozycji zależnej, na co wskazuje rekonstrukcja strukturalna:

Historyk sztuki powątpiewa w to, że XVI-wieczny zamek obronny zostanie odzyskany.

Wobec tego zdaniom tego typu przysługuje eksplikacja gramatyczna: $V N_{x}$ $N V_{q} \ldots$ W drugim przypadku rzeczownik abstrakcyjny ciąża, który także tworzy 
związek syntaktyczny z orzeczeniem (powątpiewa o ciąży), reprezentuje jeden $\mathrm{z}$ argumentów propozycji zależnej, por. rekonstrukcję:

Lekarz powątpiewa o tym że ta a ta (znana z kontekstu) kobieta zaszła w ciążę.

W tym przypadku realizuje się schemat eksplikacyjny $V N_{x} N V_{a q} \varnothing_{q}$.

$Z$ badania materiału źródłowego wynika, że możliwość występowania w pozycji AP formy $N V_{q} \ldots$ najczęściej oznacza także dopuszczalność w tej pozycji formy $N V_{a q}$. Odwrotna zależność jest jednak nieco inna: istnieje niewielka liczba czasowników dopuszczających formę $\mathrm{NV}_{\mathrm{aq}} \mathrm{w}$ pozycji $\mathrm{AP}$, ale niedopuszczających formy $N V_{q} \ldots$ Na przykład w języku rosyjskim do tej grupy należy siedem czasowników: доучивать/доучить, зубрить, надумььвать/надумать, прикидьвать/прикинуть, проникать/проникнуть, разрешать/разрешить, раскапьвать/раскопать. Niżej podano rosyjskie przykłady realizacji schematu eksplikacyjnego $V N_{x} N V_{a q} \varnothing_{q}$, dla których nie istnieją alternatywne formy z $N V_{q} \ldots$ o funkcji predykatowej:

Иван доучивает урок.

Девочка с отвращением зубрит диалектику.

Больные надумали себе некую систему измерения.

Финансисты прикинули все плюсы и минусы.

Писатель проник в психологию героя.

Политик разрешил существенный для нации вопрос.

Психолог раскопал признаки осознанности.

\section{4.}

Najwyższy stopień kompresji składniowej wykazują konstrukcje, w których argument propozycjonalny $\mathrm{w}$ ogóle nie został zrealizowany - w tej pozycji występuje zero składniowe. $Z$ walencją czasowników mentalnych wiąże się wyzerowanie bezkontekstowe, podczas gdy wyzerowanie kontekstowe (czyli elipsa) jest uwarunkowane czynnikami o charakterze zewnętrznym, często nawet ekstralingwistycznym. Większość czasowników mentalnych dopuszcza możliwość bezkontekstowego niewypełnienia pozycji $q$. W tym przypadku obiekt refleksji mentalnej nie jest konkretyzowany - zachodzi zjawisko niedeterminacji lub generalizacji, por. przykłady z trzech języków:

JĘZYK BUŁGARSKI:

Той [винаги] анализира, критикува и сравнява.

Тя [е много нерешителна и често] се двоуми.

Тя [има добра памет и бързо] запаметява.

Той [постоянно] разсъждава. 


\section{JĘZYK POLSKI:}

[Nawet] nieźle wykształceni [stale] się douczają.

Seneszak [milczał jakiś czas,] kalkulował.

Jakiś staruszek usiadł przy stoliku obok, namyślał się [długo / przez chwilę].

Osoba marzycielska [i oderwana od rzeczywistości] [zazwyczaj] przemarzy całe lata.

Rybak [siedzi na brzegu rzeki i] rozpamiętuje.

\section{JEZZYK ROSYJSKI:}

Бережков [опять] расфантазировался.

Я [постоянно] рефлексирую.

[Она не делает выводов -] он [только] созерцает.

[Он не думает -] он угадывает.

[Мысленная «диета»:] подумать[, внушить себе и похудеть].

Należy zwrócić uwagę na częstą obecność w konstrukcjach tego typu składników adiunktywnych (inaczej: okoliczników), zwykle w formie konstrukcji przyimkowo-rzeczowych, przysłówków lub partykuł, por. bułg. винаги, често, вечно, по иелите дни, съвсем, лесно itp.; pol. znowu, tylko, zazwyczaj, stale, zawsze i in.; ros. опять, только, особо, постоянно, всегда itp. W ten sposób realizuje się mechanizm kompensacji składniowej, opisany w pracy: Kiklewicz, 2007, ss. 39 i n. Mechanizm ten polega na imitacji obecności przy predykacie komplementu, tzn. jakiejkolwiek formy materialnej, wypełniającej pozycję zarezerwowaną dla AP. Adiunkt w tych przypadkach występuje jako komplement fikcjonalny. W swoim czasie Stanisław Siatkowski (Siatkowski, 1965, s. 9) pisał o „zasadzie uzupełnienia”, zgodnie z którą wprowadzenie do struktury zdaniowej syntaktemu przysłówkowego sprzyja semantyce niedeterminacji podmiotu.

Bezkontekstowe wyzerowanie pozycji AP wiąże się z realizacją semantyki nieokreśloności lub generyczności, nie stanowi jednak regularnej formy syntaktycznej w obrębie klasy czasowników mentalnych. Najczęściej ta forma jest dopuszczalna w języku rosyjskim - obejmuje 48,9\% jednostek. W języku bułgarskim jest to cecha walencyjna 30,7\% czasowników, a w języku polskim tylko 24,1\% czasowników. Za przykłady czasowników, które nie dopuszczają bezkontekstowego wyzerowania pozycji AP, mogą posłużyć następujące jednostki:

bułg. абстрахирам се, асоциирам, бъркам, вглъбявам се/вглъбя се, вдълбочавам се/вдълбоча се, виждам/видя, вниквам/вникна, внушавам си/внуша си, интересувам се, признавам/призная i in. 
pol. dowiadywać się/dowiedzieć się, interesować, kwestionować, orientować się, pamiętać, pokojarzyć, postudiować, rozważać/rozważyć, utożsamiać/utożsamić, wychwytywać/wychwycić i in.

ros. акцептировать, вскрывать/вскрыть, вызнавать/вызнать, выучивать/ выучить, доучивать/доучить, доходить/дойти, задумывать/задумать, заключать/заключить, замечать/заметить, запланировать i in.

Zauważalna jest szczególnie niska liczba czasowników dopuszczających bezkontekstowe wyzerowanie AP w konstrukcjach diatezy pochodnej, na co wskazuje porównanie poniższych zdań w języku rosyjskim:

Умный ученик - думает. // *Умный ученик - (ему) думается.

Его все обманывают, а он верит. // ^Его все обманывают, а ему верится.

Иван сидит и мечтает. // ^Иван сидит, и (ему) мечтается.

Инспектор анализирует, осмысливает, рассматривает, бесстрастно и придирчиво. // ^Инспектору анализируется, осмысливается, бесстрастно рассматривается.

Wyjątki od tej reguły są nieliczne, np.

Ему всегда кажется.

W znaczeniu ewolutywnym, gdy chodzi o czynności, stany, operacje i procesy mentalne, wyabstrahowane z przedmiotu, czasowniki zwrotne występują w określonych warunkach: albo z wykładnikiem negacji, albo przy obecności adiunktywnych modyfikatorów (np. w formie adwerbiów), por. przykłady z języka rosyjskiego:

Не думалось.

Не сочиняется.

Здесь хорошо думается.

С вами отлично медитировалось!

В тюрьме очень хорошо вспоминается.

Меня иногда осеняет.

Ярослава часто озаряет.

O roli komplementów fikcjonalnych była mowa już wcześniej, w związku $\mathrm{z}$ wyzerowaniem pozycji AP w konstrukcjach diatezy aktywnej. W konstrukcjach diatezy pochodnej (afektywnej lub pseudosubiektywnej) znaczenie takich komplementów wzrasta: usunięcie takiego okolicznika wiąże się z łamaniem normy językowej. 
Konstrukcje z wyzerowaniem pozycji AP zostały zróżnicowane ze względu na referencję (czyli odniesienie sytuacyjne). Wyodrębniono zdania sytuacyjne, wskazujące na zlokalizowaną w czasie i przestrzeni sytuację, oraz zdania generyczne, mające charakter habitualny, kwalifikujący itd. W poniższej tabeli przytoczono dane ilościowe o dopuszczalności wyzerowania w zdaniach każdego typu.

Tabela 3. Liczba czasowników dopuszczających wyzerowanie AP w zdaniach sytuacyjnych i generycznych

\begin{tabular}{|l|c|c|c|c|}
\hline \multirow{2}{*}{ Język } & \multicolumn{4}{|c|}{$\begin{array}{c}\text { Znaczenie zdania } \\
\text { z wyzerowaną pozycją AP }\end{array}$} \\
\cline { 2 - 5 } & \multicolumn{2}{|c|}{ Sytuacyjne } & \multicolumn{2}{c|}{ generyczne } \\
\hline bułgarski & 40 & $15,6 \%$ & 50 & $19,5 \%$ \\
\hline polski & 42 & $16,9 \%$ & 38 & $15,3 \%$ \\
\hline rosyjski & 89 & $27,4 \%$ & 113 & $34,8 \%$ \\
\hline Razem & \multicolumn{2}{|c|}{$167(20,1 \%)$} & \multicolumn{2}{c|}{$202(24,3 \%)$} \\
\hline
\end{tabular}

$\mathrm{Z}$ tabeli wynika, że bezkontekstowe wyzerowanie AP w zdaniach generycznych ma nieco bardziej regularny charakter niż w zdaniach sytuacyjnych. Regularność ta zachowana jest we wszystkich badanych językach, choć dysproporcja w każdym przypadku jest inna: największa w języku rosyjskim $(27,4 \%$ vs $34,8 \%$ ), a najmniejsza w języku polskim (16,9\% vs $15,3 \%)$.

Kolejnym krokiem badawczym było określenie liczby czasowników dopuszczających bezkontekstowe wyzerowanie AP tylko w zdaniach sytuacyjnych, tylko w zdaniach generycznych oraz w obydwu typach zdań. Informację na ten temat przedstawia tabela 4 .

Tabela 4. Regularność wyzerowania AP w zdaniach sytuacyjnych i generycznych

\begin{tabular}{|l|c|c|c|c|c|c|}
\hline \multirow{2}{*}{ Język } & \multicolumn{5}{|c|}{ Znaczenie zdania z wyzerowaną pozycją AP } \\
\cline { 2 - 7 } & \multicolumn{2}{|c|}{ tylko sytuacyjne } & \multicolumn{2}{c|}{$\begin{array}{c}\text { tylko } \\
\text { niesytuacyjne }\end{array}$} & \multicolumn{2}{c|}{$\begin{array}{c}\text { sytuacyjne/ } \\
\text { niesytuacyjne }\end{array}$} \\
\hline bułgarski & 29 & $11,3 \%$ & 39 & $15,2 \%$ & 11 & $4,3 \%$ \\
\hline polski & 22 & $8,8 \%$ & 18 & $7,2 \%$ & 20 & $8,0 \%$ \\
\hline rosyjski & 46 & $14,1 \%$ & 70 & $21,5 \%$ & 43 & $13,2 \%$ \\
\hline Razem & \multicolumn{2}{|c|}{$94(31,5 \%)$} & \multicolumn{2}{|c|}{$130(43,6 \%)$} & \multicolumn{2}{c|}{$74(24,8 \%)$} \\
\hline
\end{tabular}


Dane ilościowe wykazują, że w bułgarskim i rosyjskim przewagę mają czasowniki, które dopuszczają wyzerowanie AP tylko w zdaniach generycznych. W języku polskim trzy grupy czasowników pod względem liczebności są mniej więcej zrównoważone. Język bułgarski wyróżnia się ponadto tym, że występuje w nim najmniejszy procent czasowników dopuszczających wyzerowanie w zdaniach obu typów.

\section{5 .}

Po omówieniu czterech typów realizacji AP (dyskretnych, wpół dyskretnych, niedyskretnych i zerowych) należy porównać je ze względu na regularność reprezentacji w systemie każdego z badanych języków. Sumaryczną informację na ten temat zawiera poniższa tabela.

Tabela 5. Regularność typów gramatycznej realizacji pozycji AP w zdaniach z czasownikiem mentalnym

\begin{tabular}{|l|c|c|c|c|c|c|c|c|}
\hline \multirow{2}{*}{ Język } & \multicolumn{6}{|c|}{ Liczba czasowników reprezentujących typ realizacji AP } \\
\cline { 2 - 9 } & \multicolumn{2}{|c|}{$\begin{array}{c}\text { dyskretny } \\
S_{q}\end{array}$} & \multicolumn{2}{c|}{$\begin{array}{c}\text { wpół dyskretny } \\
N V_{q} / V I_{q}\end{array}$} & $\begin{array}{c}\text { niedyskretny } \\
N_{a q} \varnothing_{q}\end{array}$ & \multicolumn{2}{c|}{$\begin{array}{c}\text { zerowy } \\
\varnothing_{q}\end{array}$} \\
\hline bułgarski & 241 & $93,8 \%$ & 252 & $98,1 \%$ & 166 & $64,6 \%$ & 79 & $30,7 \%$ \\
\hline polski & 230 & $92,4 \%$ & 248 & $99,6 \%$ & 152 & $61,0 \%$ & 60 & $24,1 \%$ \\
\hline rosyjski & 294 & $90,5 \%$ & 322 & $99,1 \%$ & 215 & $66,2 \%$ & 159 & $48,9 \%$ \\
\hline Razem & 765 & $92,2 \%$ & 822 & $98,9 \%$ & 533 & $64,1 \%$ & 298 & $35,9 \%$ \\
\hline
\end{tabular}

Z danych tabeli można wnioskować, że największa liczba czasowników (dotyczy to każdego z badanych języków) dopuszcza w pozycji AP syntaktem o charakterze dyskretnym i wpół dyskretnym, a więc obecność wykładnika predykatu propozycji zależnej - w formie czasownika osobowego, rzeczownika abstrakcyjnego lub bezokolicznika. Przy tym zachodzi nieznaczna przewaga form nominalizowanych.

Szczególnie należy podkreślić wysoki stopień obecności konstrukcji ze zdaniem zależnym. Słowniki opisowe, a czasem także słowniki syntaktyczne pomijają tę formę syntaktyczną w egzemplifikacjach lub opisach właściwości walencyjnych, skupiając się na związkach syntaktycznych jednostek leksykalnych. Jest to, jak widać, niesłuszne stanowisko, gdyż zdecydowana większość czasowników, co najmniej w klasie verba mentalis, zakłada możliwość realizacji $\mathrm{AP} \mathrm{w}$ formie zdania zależnego. 
W przypadku średnio 64,1\% czasowników dopuszczalna jest nieobecność predykatu propozycji zależnej. Jest to przypadek bardziej intensywnej kompresji syntaktycznej, która powoduje, że interpretacja semantyczna zdania w większym stopniu wymaga uwzględnienia kontekstu lub konsytuacji. Ostatnio dużo (szczególnie w nurcie lingwistyki komunikacyjnej) pisze się o kontekstocentrycznym charakterze działalności językowej, ale nasz materiał nie potwierdza tej tezy: duża liczba jednostek czasownikowych nie przewiduje takiego typu realizacji AP, a więc zjawisko inferencji w przypadku tych jednostek ma raczej marginalny, w każdym razie mało istotny charakter.

Badanie wykazało, że nasilenie kompresji syntaktycznej wiąże się z zawężeniem kręgu czasowników, dla których jest charakterystyczny taki rodzaj walencji. Najmniej liczną grupę tworzą czasowniki, które dopuszczają bezkontekstowe wyzerowanie AP; szczególnie wyróżnia się pod tym względem język polski, w którym tylko 24\% czasowników reprezentuje ten typ łączliwości syntaktycznej.

Omówione wyżej regularności dotyczą predyspozycji, którymi dysponują jednostki czasownikowe w systemie języka. Nie należy przy tym zakładać, że podobne proporcje zachowują się $\mathrm{w}$ aspekcie performancji, tzn. przekładają się na częstość występowania poszczególnych typów realizacji AP w mowie. W projekcie ten drugi aspekt funkcjonowania czasowników mentalnych nie był badany, choć oczywiście powinien zostać zbadany, gdyż wówczas można będzie się dowiedzieć, jaka jest relacja między systemem języka a jego realizacją w badanym zakresie.

\section{6 .}

Z jednej strony w strukturze składniowej zachodzą procesy kompresji, gdy pewne elementy treści AP nie zostają formalnie wyeksplikowane. Z drugiej strony zachodzi wręcz odwrotny proces rozszczepienia, polegający na wypełnieniu dwóch pozycji przy predykacie zdania głównego - takich, które reprezentują ten sam AP. Konfiguracje tych składników są różne: predykat propozycji zależnej + argument albo argument + argument. Dane o regularności realizacji poszczególnych typów rozszczepienia AP przytaczamy w poniższej tabeli. 
Tabela 6. Regularność typów rozszczepienia AP w zdaniach w czasownikiem mentalnym

\begin{tabular}{|c|c|c|c|c|}
\hline Typ rozszczepienia & $\begin{array}{c}\text { Język } \\
\text { bułgarski }\end{array}$ & $\begin{array}{l}\text { Język } \\
\text { polski }\end{array}$ & $\begin{array}{l}\text { Język } \\
\text { rosyjski }\end{array}$ & Razem \\
\hline$S_{a q} S_{q}$ & 0 & 0 & 3 & 3 \\
\hline S. $N V_{a q}$ & 0 & 3 & 6 & 9 \\
\hline$S_{a q} N V_{P q} \ldots \varnothing_{V q}$ & 0 & 2 & 0 & 2 \\
\hline$S_{a q} A d j_{P q} \ldots \varnothing_{V q}$ & 0 & 0 & 4 & 4 \\
\hline$N V_{a q} S_{q}$ & 0 & 0 & 6 & 6 \\
\hline$S_{q} N_{a q}$ & 2 & 12 & 4 & 18 \\
\hline$N_{a q} S_{q}$ & 69 & 8 & 13 & 90 \\
\hline$S_{a q} A d v_{P q}$ & 2 & 0 & 0 & 2 \\
\hline$N V_{a q} N V_{q} \ldots$ & 0 & 2 & 1 & 3 \\
\hline$N V_{a q} N V_{P q} \ldots \varnothing_{V q}$ & 10 & 17 & 47 & 74 \\
\hline$N V_{a q} \ldots N V_{a q} \varnothing_{q}$ & 2 & 2 & 7 & 11 \\
\hline$N V_{a q} A d j_{P q} \ldots \varnothing_{V q}$ & 0 & 13 & 19 & 32 \\
\hline$N V_{a q} A d v_{P q} \ldots \varnothing_{V q}$ & 0 & 3 & 0 & 3 \\
\hline$V I_{a q} \ldots N V_{P q} \ldots \varnothing_{V q}$ & 0 & 0 & 2 & 2 \\
\hline$V I_{a q} A d j_{P q} \ldots \varnothing_{V q}$ & 0 & 0 & 2 & 2 \\
\hline$N_{a q} N V_{q} \ldots$ & 33 & 7 & 17 & 127 \\
\hline$N V_{q} \ldots N_{a q}$ & 2 & 5 & 7 & 14 \\
\hline$N V_{a q} N_{a q} \emptyset_{q}$ & 2 & 0 & 0 & 2 \\
\hline$N_{a q} N V_{P q} \ldots \varnothing_{V q}$ & 0 & 7 & 11 & 18 \\
\hline$N V_{P q} \ldots N_{a q} \varnothing_{V q}$ & 0 & 1 & 0 & 1 \\
\hline$N V_{a q} N_{P q} \ldots \varnothing_{V q}$ & 0 & 0 & 1 & 1 \\
\hline$N_{a q} A d j_{P q} \ldots \varnothing_{V q}$ & 4 & 5 & 13 & 22 \\
\hline$N_{a q} A d v_{P q} \varnothing_{V q}$ & 1 & 2 & 0 & 3 \\
\hline$N_{a q} N_{P q} \varnothing_{V q}$ & 37 & 54 & 47 & 138 \\
\hline$N_{a q} N_{a q} \varnothing_{q}$ & 1 & 1 & 7 & 9 \\
\hline Razem & 165 & 144 & 217 & 596 \\
\hline
\end{tabular}

Mimo że typów rozszczepienia, ogólnie rzecz biorąc, jest dużo, większość z nich ma charakter jednostkowy, a niektóre zostały odnotowane tylko w jednym $z$ badanych języków. Najbardziej regularnie są realizowane cztery schematy eksplikacyjne: 
$\mathrm{N}_{\mathrm{aq}} \mathrm{N}_{\mathrm{Pq}} \varnothing_{\mathrm{Vq}}$

$\mathrm{N}_{\mathrm{aq}} \mathrm{NV}_{\mathrm{q}} \cdots$

$\mathrm{N}_{\mathrm{aq}} \mathrm{S}_{\mathrm{q}}$

$\mathrm{NV}_{\mathrm{aq}} \mathrm{NV}_{\mathrm{Pq}} \ldots \varnothing_{\mathrm{Vq}}$

Jak widzimy, są to w większości konstrukcje zdaniowe z wykładnikiem argumentu substancjalnego $\left(N_{a q}\right)$ w pozycji dopełnienia bliższego. W każdym języku przeważają czasowniki mentalne, które dopuszczają dwie pozycje dopełnienia: dla wykładnika argumentu propozycji zależnej i dla orzecznika (jako składnika predykatu). Niżej przytoczono przykłady zdań tego typu.

JĘZYK BUŁGARSKI:

Професорът се заинтересува от Кумранските ръкописи като литературен паметник.

Засъмнявах се в Николай като председател.

Отхвърлям Ницше като философ.

Представих си Иван като зрител на въпросния сериал.

JĘZYK POLSKI:

Waldek pomyślał o Izie jako o żonie.

Wątpię w niego jako fachowca.

Tomek wyczuł w koledze donosiciela.

Futerał zdawał się Markowi strzelbą.

JEZZYK ROSYJSKI:

Он думает о вещах как о живых людях.

Мы запомним его как одного из талантливейших творцов XX века.

Он открыл ее как женщину.

И такого-то человека посчитал я другом.

Jak widać z przytoczonych przykładów, schemat eksplikacyjny $N_{a q} N_{P q} \varnothing_{V q}$ realizuje się $\mathrm{w}$ konstrukcjach syntaktycznych dwóch typów: $\mathrm{z}$ przyimkiem

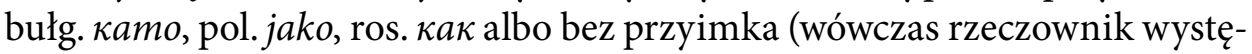
puje w narzędniku).

\section{7.}

Z przeprowadzonej analizy wynikają niektóre wnioski konfrontatywne. Przede wszystkim należy zwrócić uwagę na nieco odmienną regularność zjawiska kompresji AP. Różnice te są najbardziej zauważalne w przypadku wyzerowania pozycji AP: największa dopuszczalność takiej formy składnio- 
wej występuje w języku rosyjskim (prawie 50\% czasowników), najmniejsza w języku polskim (ok. 24\%).

Wyzerowanie pozycji AP realizuje się w warunkach określonej semantyki zdaniowej: sytuacyjnej (referencyjnej) lub generycznej. W punkcie 2.4. zaznaczono, że pod tym względem badane języki nieznacznie się różnią. Tak więc w bułgarskim i rosyjskim większa liczba czasowników dopuszcza wyzerowanie pozycji AP w zdaniach generycznych, podczas gdy w języku polskim te grupy czasowników są pod względem wielkości podobne. W języku bułgarskim ponadto jest najmniejszy odsetek czasowników $\mathrm{z}$ realizacją $\mathrm{AP} \mathrm{w}$ formie $\varnothing_{q}$ zarówno w zdaniach sytuacyjnych, jak i generycznych.

W punkcie 2.5. zauważono, że konstrukcje dyskretne, wpół dyskretne i niedyskretne w trzech językach realizują się z podobną regularnością. To jednak nie wyklucza pewnych różnic dotyczących poszczególnych jednostek. $\mathrm{Na}$ przykład różny jest zakres nominalizacji AP polskiego czasownika przypuszczać i jego bułgarskiego odpowiednika предполагам. Bułgarski wyraz dopuszcza wykładnik znominalizowany, a polski - nie, por.

bułg. Полицията предполага действия на разузнаването.

pol. Policja przypuszcza, że są to działania wywiadu.

W podobny sposób bułgarski i polski odpowiedniki leksykalne досещам се domyślać się / domyślić się wykazują odmienne predyspozycje co do wypełnienia pozycji AP w formie substancjalnej grupy imiennej $N_{a q}$, na co wskazują następujące ilustracje zdaniowe:

bułg. Марин се досещя, че съседа му го е предал.

bułg. Марин се досеща за предателството на съседа си.

bułg. Марин се досеща за съседа си.

pol. Marian domyśla się, że sąsiad go zdradził.

pol. Marian domyśla się zdrady sąsiada.

pol. ${ }^{\star M a r i a n}$ domyśla się sąsiada.

Za inny przykład takiego zróżnicowania może posłużyć czasownik pozwalać i jego odpowiedniki bułgarskie i rosyjskie:

pol. Pozwalam im wyjechać / aby wyjechali. // Pozwalam im na wyjazd.

bułg. Разрешавам им да заминат. // *Разрешавам им заминаване.

ros. Я разрешаю тебе выступить. // ${ }^{\star}$ Я разрешаю тебе выступление.

Jak widać, $\mathrm{w}$ języku polskim $\mathrm{w}$ zdaniach $\mathrm{z}$ czasownikiem pozwalać prawa pozycja może być wypełniona rzeczownikiem abstrakcyjnym $\left(N V_{q} \operatorname{lub} N V_{a q}\right)$, 
podczas gdy w języku bułgarskim i rosyjskim taki typ kombinatoryczny jest zablokowany. Co prawda, w materiale językowym można znaleźć także podobne zdania bułgarskie i rosyjskie, np.

bułg. Разрешавам публикуването на книга.

bułg.Разрешавам на щастливите събития да ми се наредят на опашка,за да им се случа аз.

bułg. Разрешавам разпореждане със сумата от 2880 лв.

ros. После долгих уговоров она неохотно разрешила поездку.

ros. Хотя иногда я и разрешаю себе подобные надежды.

Należy jednak zaznaczyć, że takie konstrukcje są rzadkie, a jeśli występują, są kontekstowo uwarunkowane i stylistycznie nacechowane, a niektóre z nich (np. ros. разрешить поездку) mają sfrazeologizowany charakter.

Jedną z form kompresji składniowej jest realizacja AP w postaci bezokolicznika jako wykładnika predykatu propozycji zależnej. W rozdziale 2.2. już zaznaczono, że w języku rosyjskim zakres używania formy infinitywnej czasownika jest szerszy niż w języku polskim (w języku bułgarskim, jak wiadomo, takie formy nie występują). Istnieją rosyjskie zdania z bezokolicznikiem w pozycji przyczasownikowej, których nie da się w sposób strukturalnie adekwatny przetłumaczyć na język polski: należy albo zmienić czasownik osobowy, albo użyć innej formy realizacji AP, na co wskazują następujące przykłady:

ros. Он внушил себе ориентироваться. // pol. Wmówił sobie, że musi się orientować.

ros. Воевода вымыслил закрутить дело. // pol. Wojewoda wymyślił pewną sprawę.

ros. Иногда думается уйти ото всех. // pol. Czasem człowiek chce odejść od wszystkich.

ros. Один из боевиков, воспользовавшись остановкой, надумал помочиться. // pol. Pewien bojowiec, korzystając z okoliczności, postanowił oddać mocz.

ros. Она сообразила провести обе группы через описанный выше тест. // pol. Zrozumiała, że warto zastosować do obydwu grup opisany wyżej test.

W zakresie dopuszczalności rozszczepienia AP, jak zaznaczono w punkcie 2.6., badane języki wykazują duże podobieństwo, jednak zachodzą też pewne różnice. W języku bułgarskim najbardziej regularnie realizowanym typem rozszczepienia jest $N_{a q} S_{q}$, który w polskim, a także w rosyjskim wykazie schematów eksplikacyjnym zajmuje 5. miejsce. Ten typ rozszczepienia argumentu propozycjonalnego realizuje się $\mathrm{np}$. w bułgarskich zdaniach: 
Въобразих си Ана, как пее на сцена.

Замечтах се за Иван, че ще го видя тази вечер.

Измъдрих за него, че може да кандидатства икономика.

Седнах и се поразмислих за приятелите, че винаги ще ми липсват.

W języku polskim zwraca uwagę regularność realizacji innego typu rozszczepienia: $N_{a q} N_{P q} \varnothing_{V q}$. Są to konstrukcję zdaniowe, w których AP jest reprezentowany przez dwie grupy imienne o znaczeniu substancjalnym, z których jedna jest wykładnikiem argumentu, a druga - wykładnikiem predykatu (orzecznikiem) propozycji zależnej. W języku bułgarskim i rosyjskim takie konstrukcje są mniej regularne. Są to zdania typu:

JĘZYK BUŁGARSKI:

Открих я като певица.

Оцених брат си като специалист.

Виждам Станишев като президент.

Магнетичната Вергиния Маркова запомнихме като момичето с красивия шал и чантичка.

Спомням си Иван като много отговорен мъж.

JĘZYK POLSKI:

Pracownicy myśleli o dyrektorze jako o osobie odpowiedzialnej za bankructwo firmy.

Znajoma powątpiewa w męża jako pomocnika.

Wierzę w niego jako dobrego ojca.

Adam wyobraża sobie swoją przyjaciółkę jako modelkę.

Zamyślała się często nad tym starym samochodem jako pojazdem ich rodziny.

JĘZYK ROSYJSKI:

Многие музыканты воспринимают скрипку как любовницу.

Владимир Кавсадзе, директор Тбилисского цирка, запомнился нам как друг артистов.

Я знаю его как профессионального тыловика.

Сегодня ландшафтным архитектором мнит себя практически каждый.

Я сомневаюсь в Троен как в актрисе.

Różnice między językami (w zakresie rozszczepienia AP) mają czasem pojedynczy, okazjonalny charakter. Chodzi o konstrukcje, które występują w jednym języku, ale nie zostały odnotowane w innych. Takich przypadków, jak wynika $\mathrm{z}$ tabeli 4 , jest dość dużo, jednak z uwagi na nieliczną grupę czasowników, które dopuszczają te lub inne typy rozszczepienia AP, trudno twierdzić, że stanowi to istotną cechę typologiczną któregoś z języków. Tak 
więc w języku rosyjskim możliwe jest rozszczepienie argumentu propozycjonalnego w następującej postaci: $S_{a q} S_{q}$ :

О том, что муж не вернулся, она думает, что это - ее собственная вина.

О том, что произошло в городе, я подумал, что это - провокация спецслужб.

О том, что было со мной, я только помнил, как входил в церковь.

Mamy tu do czynienia z wyjątkową sytuacją, gdy jeden AP jest realizowany w postaci dwóch zdań zależnych, tworzących (jako aktanty sentencjonalne) związki syntaktyczne $z$ orzeczeniem zdania głównego. Ten typ konstrukcji jednak jest uzasadniony $\mathrm{z}$ uwagi na fakt, że struktura argumentowa $q$ bywa bardziej lub mniej złożona. Na przykład pierwsze z przytoczonych wyżej zdań jest rezultatem przekształcenia zdania wyjściowego, którego strukturę można zapisać następująco:

$$
\begin{aligned}
& P(x, P(x, P(x \ldots))) \\
& \text { ДУМАЕТ (она, ВИНОВАТА (она, НЕ ВЕРНУЛСЯ (муж))) }
\end{aligned}
$$

W strukturze propozycjonalnej $q$ znajduje się w obszarze walencji drugiego (wewnętrznego) predykatu, natomiast realizacja syntaktyczna w postaci rozszczepienia propozycji $P(x, q)$ polega na tym, że zarówno $P$, jak i $q$ zostają przeniesione w pozycje przy orzeczeniu zdania głównego. Można to pokazać symbolicznie:

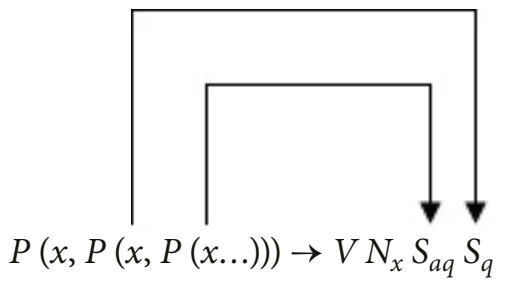

Niektóre typy rozszczepienia AP mają charakter potoczny albo wręcz potencjalny. Ważne jest jednak, że jako obiekty lingwistyczne nie są one sprzeczne z systemem języka, więc mogą zostać zrealizowane, szczególnie przy wsparciu określonych czynników kontekstowych.

Podsumowując, należy skonstatować, że formy gramatycznej realizacji AP w badanych językach słowiańskich - na poziomie schematów eksplikacyjnych (jak je zdefiniował Karolak) - przeważnie się powtarzają. Zasoby jednostek leksykalnych 
(czasowników mentalnych), przyporządkowanych każdemu z tych typów syntaktycznych $\left(S_{q}, N V_{q}, N V_{a q}, N_{a q}\right)$ liczbowo zasadniczo się nie różnią, można więc twierdzić, że pod tym względem systemy badanych języków są zrównoważone. Najbardziej zauważalne różnice dotyczą realizacji AP w formie bezokolicznika, a także realizacji zerowej. Inaczej wyglądają także niektóre procesy rozszczepienia AP.

Gdyby uwzględnić kolejny poziom specyfikacji syntaktycznej - schematy zdaniowe, ufundowane na znaczeniach gramatycznych, w pierwszej kolejności znaczeniach kategorii przypadka - wówczas można byłoby odnotować większą liczbę zjawisk różnicujących każdy język. Na przykład dotyczy to zjawiska diatezy (aktywnej, pseudosubiektywnej i afektywnej), które jest o wiele bardziej charakterystyczne dla języka rosyjskiego w porównaniu z bułgarskim i polskim. Ten aspekt składni słowiańskich czasowników mentalnych zbadano w jednej z poprzednich publikacji (Kiklewicz, 2017d, ss. 257 i n.).

\section{Bibliografia}

Karolak, S. (1984). Składnia wyrażeń predykatywnych. W Z. Topolińska (Red.), Gramatyka współczesnego języka polskiego: Składnia (ss. 11-112). Warszawa: PWN.

Karolak, S. (2002). Podstawowe struktury składniowe języka polskiego. Warszawa: Instytut Slawistyki PAN.

Kiklewicz, A. (2007). Tak zwane człony przyłączone a status referencyjny wypowiedzi. Poradnik Językowy, 9, 29-45.

Kiklewicz, A. (2009). Zum propositionalen Explikationsmodell einer semantischen Kategorie. Kwartalnik Neofilologiczny, 56(1), 63-78.

Kiklewicz, A. (2014). Nowe gatunki - nowa składnia? Realizacja podstawowych struktur zdaniowych $\mathrm{w}$ tekstach forów internetowych (na przykładzie zdań z verba cogitandi). W D. Scheller-Boltz (Red.), Die polnische Sprache - 25 Jahre nach der Wende (ss. 285-310). Hildesheim: Olms.

Kiklewicz, A. (2017a). Formy realizacji argumentu propozycjonalnego w rosyjskich zdaniach z czasownikiem mentalnym: Przestrzeganie, kompresja, rozszczepienie. Prace Językoznawcze, 19(3), 71-92.

Kiklewicz, A. (2017b). Rosyjskie czasowniki mentalne jako klasa semantyczna. Przeglą Rusycystyczny, 2017(2(158)), 93-117.

Kiklewicz, A. (2017c). Russian mental verbs as a semantic class. Јужнословенски филолог, 73(3-4), 7-28. https://doi.org/10.2298/JFI1704007K

Kiklewicz, A. (2017d). Walencja rosyjskich czasowników mentalnych w konstrukcjach diatezy afektywnej. Prace Filologiczne, 70, 247-268. 
Kiklewicz, A. (2017e). Walencja rosyjskich czasowników mentalnych w świetle składni eksplikacyjnej. Studia z Filologii Polskiej i Słowiańskiej, 52, 110-138. https://doi.org/10.11649 /sfps.2017.006

Kiklewicz, A., \& Korytkowska, M. (Red.). (2010). Podstawowe struktury zdaniowe języków słowiańskich: białoruski, bułgarski, polski. Olsztyn: CBEW.

Kiklewicz, A., \& Korytkowska, M. (2012). Eksplikacyjny model opisu składniowego i jego zastosowanie w leksykografii języków słowiańskich (na przykładzie języka polskiego i rosyjskiego). W M. Korytkowska (Red.), Z polskich studiów slawistycznych: Seria 12. Językoznawstwo: Prace na XV Międzynarodowy Kongres Slawistów w Mińsku 2013 (ss. 81-89). Warszawa: Instytut Slawistyki PAN.

Kiklewicz, A., \& Korytkowska, M. (2013). Modelowanie płaszczyzny syntaktycznej a segmentacja hasła słownikowego (na przykładzie języków słowiańskich). Biuletyn PTJ, 68, 49-68.

Kokot-Góra K. (2015a). Łączliwość leksykalna jako realizacja struktury semantycznej wyrazu (na przykładzie kolokacji rzeczownika nagroda). W I. Kosek, R. Makarewicz, \& K. Zawilska (Red.), Nowe zjawiska w języku, tekście i komunikacji (T. 5, ss. 114-125). Olsztyn: Wydawnictwo UWM.

Kokot-Góra, K. (2015b). Nagroda and nagradzanie (reward and awarding a prize) in a semantic syntax model. Prace Językoznawcze, 17(4), 25-39.

Korytkowska, M. (1992). Typy pozycji predykatowo-argumentowych. Warszawa: Instytut Slawistyki PAN.

Korytkowska, M. (2013). Slawistyka polska w minionym sześćdziesięcioleciu: Synchroniczne prace językoznawcze z zakresu morfologii i składni. Rocznik Slawistyczny, 62, 39-54.

Korytkowska, M. (2014). O predykatorach analitycznych w strukturze argumentu propozycjonalnego (na materiale języka bułgarskiego i polskiego). Acta Universitatis Wratislaviensis: Slavica Wratislaviensia, 8, 207-217.

Korytkowska, M. (2017a). Intensja czy ekstensja? (O pewnych dylematach przy analizie struktur predykatowo-argumentowych). Prace Filologiczne, 70, 305-316.

Korytkowska, M. (2017b). O granicy klasy semantycznej czasowników emotywnych. W A. Dudziak \& J. Orzechowska (Red.), Język i tekst w ujęciu strukturalnym i funkcjonalnym: Ksiega jubileuszowa dedykowana Profesorowi Aleksandrowi Kiklewiczowi z okazji 60. urodzin (ss. 207-216). Olsztyn: CBEW.

Korytkowska, M., \& Kiklewicz, A. (2013). O modelu składni semantycznej w perspektywie opisu leksykograficznego czasowników (na materiale języka bułgarskiego i polskiego). W Л. Крумова-Цветкова et al. (Red.), 70 години българска академична лексикография (ss. 124-132). София: Академично издателство „Проф. Марин Дринов”.

Korytkowska, M., \& Kiklewicz, A. (2016). Opis właściwości walencyjnych czasowników na podstawie teorii składni eksplikacyjnej - problemy konfrontatywne i leksykograficzne (na przykładzie języka bułgarskiego, polskiego i rosyjskiego). W K. Skwarka \& E. Karczmarska (Red.), Výzkum slovesné valence ve slovanských zemích (ss. 291-304). Praha: Slovanský ústav AV ČR. 
Korytkowska, M., \& Mazurkiewicz-Sułkowska, J. (2014). O konfrontatywnym badaniu polskich i bułgarskich czasowników mentalnych. Rocznik Slawistyczny, 63, 47-76.

Mazurkiewicz-Sułkowska, J. (2016). Struktura predykatowo-argumentowa bułgarskich czasowników poliprefiksalnych (na przykładzie verba mentalis). Rozprawy Komisji Językowej ŁTN, 62, 59-70.

Papierz, M. (2013). Podstawowe struktury składniowe współczesnego języka słowackiego. Kraków: Lexis. de Saussure, F. (2002). Kurs językoznawstwa ogólnego. Warszawa: PWN.

Siatkowski, S. (1965). О принципах классификации простого предложения в современном русском языке. Русский язык в школе, 1965(3), 3-11.

Szumska, D. (2017). Struktura predykatowo-argumentowa jako narzędzie analizy tekstu: pro et contra. Studia z Filologii Polskiej i Słowiańskiej, 52, 264-277. https://doi.org/10.11649 /sfps.2017.014

Warchala, J. (2003). Kategoria potoczności w języku. Katowice: Wydawnictwo UŚ.

Апресян, Ю. Д. (Red.). (2004). Новый объяснительный словарь синонимов русского языка. Москва: Языки русской культуры.

Викторова, К. (2005). Функционален развой на да-конструкцията в съвременния български език. W C. Котороева (Red.), Аргументна структура: Проблеми на простото и сложното изречение (ss. 185-224). София: СемаРШ.

Иванова, Ю. И. (2014). Русские параллели болгарской да-конструкции. W 3. Тополињска (Red.), Субјунктив со посебен осврт на македонските да-конструкиии (ss. 107-161). Скопје: Македонска академија на науките и уметностите.

Киклевич, А. (2015). Синтаксическая информация в лексикографическом описании слова (на примере ментальных глаголов). W A. Kamalova (Red.), Русская лексикография вчера, сегодня, завтра (ss. 33-57). Olsztyn: CBEW.

Киклевич, А. (2016а). Русский язык в модели экспликативного синтаксиса. Przeglą Wschodnioeuropejski, 7(1), 133-152.

Киклевич, А. (2016b). Синтаксические характеристики русских и польских интернетфорумов (на материале простых и сложных предложений с ментальными предикатами). W В. Tosović \& A. Wonisch (Red.), Interaktion von Internet und Stilistik, Internet und Stil (ss. 93-110). Graz: Universität Graz.

Киклевич, А., \& Корытковская, М. (2012). Экспликативный синтаксис как информационная база лексикографического описания глаголов (на материале польского и русского языков). Acta Linguistica Petropolitana, 8(3), 279-297.

Котова, Н., \& Янакиев, М. (2001). Грамматика болгарского языка для владеющих русским языком. Москва: Издательство МГУ.

Норман, Б. Ю. (1994). Грамматика говорящего. Санкт-Петербург: Издательство СПбГУ. 


\section{Bibliography (Transliteration)}

Apresian, I. D. (Ed.). (2004). Novy̌̆ ob"iasnitel'ny̆ slovar' sinonimov russkogo iazyka. Moskva: IAzyki russkoĭ kul'tury.

Ivanova, I. I. (2014). Russkie paralleli bolgarskoĭ da-konstruktsii. In Z. Topolinjska (Ed.), Subjunktiv so poseben osvrt na makedonskite da-konstrukcii (pp. 107-161). Skopje: Makedonska akademija na naukite i umetnostite.

Karolak, S. (1984). Składnia wyrażeń predykatywnych. In Z. Topolińska (Ed.), Gramatyka współczesnego języka polskiego: Składnia (pp. 11-112). Warszawa: PWN.

Karolak, S. (2002). Podstawowe struktury składniowe języka polskiego. Warszawa: Instytut Slawistyki PAN.

Kiklevich, A. (2015). Sintaksicheskaia informatsiia v leksikograficheskom opisanii slova (na primere mental'nykh glagolov). In A. Kamalova (Ed.), Russkaia leksikografiia vchera, segodnia, zavtra (pp. 33-57). Olsztyn: CBEW.

Kiklevich, A. (2016a). Russkiǔ iazyk v modeli èksplikativnogo sintaksisa. Przegląd Wschodnioeuropejski, 7(1), 133-152.

Kiklevich, A. (2016b). Sintaksicheskie kharakteristiki russkikh i pol'skikh internet-forumov (na materiale prostykh i slozhnykh predlozheniǔ s mental'nymi predikatami). In B. Tosović \& A. Wonisch (Eds.), Interaktion von Internet und Stilistik, Internet und Stil (pp. 93-110). Graz: Universität Graz.

Kiklevich, A., \& Korytkovskaia, M. (2012). Ėksplikativnyı̌ sintaksis kak informatsionnaia baza leksikograficheskogo opisania glagolov (na materiale pol'skogo i russkogo iazykov). Acta Linguistica Petropolitana, 8(3), 279-297.

Kiklewicz, A. (2007). Tak zwane człony przyłączone a status referencyjny wypowiedzi. Poradnik Językowy, 9, 29-45.

Kiklewicz, A. (2009). Zum propositionalen Explikationsmodell einer semantischen Kategorie. Kwartalnik Neofilologiczny, 56(1), 63-78.

Kiklewicz, A. (2014). Nowe gatunki - nowa składnia? Realizacja podstawowych struktur zdaniowych w tekstach forów internetowych (na przykładzie zdań z verba cogitandi). In D. Scheller-Boltz (Ed.), Die polnische Sprache - 25 Jahre nach der Wende (pp. 285-310). Hildesheim: Olms.

Kiklewicz, A. (2017a). Formy realizacji argumentu propozycjonalnego w rosyjskich zdaniach z czasownikiem mentalnym: Przestrzeganie, kompresja, rozszczepienie. Prace Językoznawcze, 19(3), 71-92.

Kiklewicz, A. (2017b). Rosyjskie czasowniki mentalne jako klasa semantyczna. Przeglad Rusycystyczny, 2017(2(158)), 93-117.

Kiklewicz, A. (2017c). Russian mental verbs as a semantic class. Južnoslovenski filolog, 73(3-4), 7-28. https://doi.org/10.2298/JFI1704007K

Kiklewicz, A. (2017d). Walencja rosyjskich czasowników mentalnych w konstrukcjach diatezy afektywnej. Prace Filologiczne, 70, 247-268. 
Kiklewicz, A. (2017e). Walencja rosyjskich czasowników mentalnych w świetle składni eksplikacyjnej. Studia z Filologii Polskiej i Słowiańskiej, 52, 110-138. https://doi.org/10.11649/sfps. 2017.006

Kiklewicz, A., \& Korytkowska, M. (2012). Eksplikacyjny model opisu składniowego i jego zastosowanie w leksykografii języków słowiańskich (na przykładzie języka polskiego i rosyjskiego). In M. Korytkowska (Ed.), Z polskich studiów slawistycznych: Seria 12. Językoznawstwo: Prace na XV Międzynarodowy Kongres Slawistów w Mińsku 2013 (pp. 81-89). Warszawa: Instytut Slawistyki PAN.

Kiklewicz, A., \& Korytkowska, M. (2013). Modelowanie płaszczyzny syntaktycznej a segmentacja hasła słownikowego (na przykładzie języków słowiańskich). Biuletyn PTJ, 68, 49-68.

Kiklewicz, A., \& Korytkowska, M. (Eds.). (2010). Podstawowe struktury zdaniowe języków słowiańskich: białoruski, bułgarski, polski. Olsztyn: CBEW.

Kokot-Góra K. (2015a). Łączliwość leksykalna jako realizacja struktury semantycznej wyrazu (na przykładzie kolokacji rzeczownika nagroda). In I. Kosek, R. Makarewicz, \& K. Zawilska (Eds.), Nowe zjawiska w języku, tekście i komunikacji (Vol. 5, pp. 114-125). Olsztyn: Wydawnictwo UWM.

Kokot-Góra, K. (2015b). Nagroda and nagradzanie (reward and awarding a prize) in a semantic syntax model. Prace Językoznawcze, 17(4), 25-39.

Korytkowska, M. (1992). Typy pozycji predykatowo-argumentowych. Warszawa: Instytut Slawistyki PAN.

Korytkowska, M. (2013). Slawistyka polska w minionym sześćdziesięcioleciu: Synchroniczne prace językoznawcze z zakresu morfologii i składni. Rocznik Slawistyczny, 62, 39-54.

Korytkowska, M. (2014). O predykatorach analitycznych w strukturze argumentu propozycjonalnego (na materiale języka bułgarskiego i polskiego). Acta Universitatis Wratislaviensis: Slavica Wratislaviensia, 8, 207-217.

Korytkowska, M. (2017a). Intensja czy ekstensja? (O pewnych dylematach przy analizie struktur predykatowo-argumentowych). Prace Filologiczne, 70, 305-316.

Korytkowska, M. (2017b). O granicy klasy semantycznej czasowników emotywnych. In A. Dudziak \& J. Orzechowska (Eds.), Język i tekst w ujęciu strukturalnym i funkcjonalnym: Księga jubileuszowa dedykowana Profesorowi Aleksandrowi Kiklewiczowi z okazji 60. urodzin (pp. 207-216). Olsztyn: CBEW.

Korytkowska, M., \& Kiklewicz, A. (2013). O modelu składni semantycznej w perspektywie opisu leksykograficznego czasowników (na materiale języka bułgarskiego i polskiego). In L. KrumovaTSvetkova et al. (Eds.), 70 godini bŭlgarska akademichna-leksikografiia (pp. 124-132). Sofiia: Akademichno izdatelstvo "Prof. Marin Drinov".

Korytkowska, M., \& Kiklewicz, A. (2016). Opis właściwości walencyjnych czasowników na podstawie teorii składni eksplikacyjnej - problemy konfrontatywne i leksykograficzne (na przykładzie języka bułgarskiego, polskiego i rosyjskiego). In K. Skwarka \& E. Karczmarska (Eds.), Výzkum slovesné valence ve slovanských zemích (pp. 291-304). Praha: Slovanský ústav AV ČR.

Korytkowska, M., \& Mazurkiewicz-Sułkowska, J. (2014). O konfrontatywnym badaniu polskich i bułgarskich czasowników mentalnych. Rocznik Slawistyczny, 63, 47-76. 
Kotova, N., \& IAnakiev, M. (2001). Grammatika bolgarskogo iazyka dlia vladeiushchikh russkim iazykom. Moskva: Izdatel'stvo MGU.

Mazurkiewicz-Sułkowska, J. (2016). Struktura predykatowo-argumentowa bułgarskich czasowników poliprefiksalnych (na przykładzie verba mentalis). Rozprawy Komisji Językowej ŁTN, 62, 59-70.

Norman, B. I. (1994). Grammatika govoriashchego. Sankt-Peterburg: Izdatel'stvo SPbGU.

Papierz, M. (2013). Podstawowe struktury składniowe współczesnego języka słowackiego. Kraków: Lexis. de Saussure, F. (2002). Kurs językoznawstwa ogólnego. Warszawa: PWN.

Siatkowski, S. (1965). O printsipakh klassifikatsii prostogo predlozheniia v sovremennom russkom iazyke. Russkiu iazyk v shkole, 1965(3), 3-11.

Szumska, D. (2017). Struktura predykatowo-argumentowa jako narzędzie analizy tekstu: pro et contra. Studia z Filologii Polskiej i Słowiańskiej, 52, 264-277. https://doi.org/10.11649 /sfps.2017.014

Viktorova, K. (2005). Funktsionalen razvoŭ na $d a$-konstruktsiiata v sŭvremenniia bŭlgarski ezik. In S. Kotoroeva (Ed.), Argumentna struktura: Problemi na prostoto i slozhnoto izrechenie (pp. 185-224). Sofiia: SemaRSh.

Warchala, J. (2003). Kategoria potoczności w języku. Katowice: Wydawnictwo UŚ.

\section{Forms of Representation of Propositional Argument in Bulgarian, Polish and Russian Expressions Based on the Mental Predicate}

\section{Summary}

This article offers a discussion of Bulgarian, Polish and Russian mental verbs from the perspective of syntactic valence. The author examines grammatical forms of propositional argument in sentences with mental verbs which represent predicate-argument structure $P(x, q)$. All syntactic forms in the focus of this study are classified into several patterns: observance, compression and splitting. The author demonstrates that what they involve is analogical reflection of propositional structure, greater or smaller compression of propositional argument, or its segmentation and doubling of syntactic position. The author examines the regularity of implementation of each grammatical form in Bulgarian, Polish and Russian on the basis of relevant quantitative data. 


\section{Formy reprezentacji argumentu propozycjonalnego w bułgarskich, polskich i rosyjskich zdaniach ufundowanych na predykacie mentalnym}

\section{Streszczenie}

Tematem prezentowanego artykułu są bułgarskie, polskie i rosyjskie czasowniki mentalne, badane w perspektywie walencji syntaktycznej. Autor analizuje gramatyczne formy realizacji argumentu propozycjonalnego w zdaniach z czasownikami mentalnymi w pozycji orzeczenia, które reprezentują strukturę predykatowo-argumentową $P(x, q)$. Wszystkie formy syntaktyczne podzielono na kilka typów: przestrzeganie, kompresja i rozszczepienie. Autor pokazuje, że w tym zakresie mamy do czynienia $\mathrm{z}$ kalkowaniem struktury propozycjonalno-semantycznej, z mniej lub bardziej intensywną kompresją argumentu propozycjonalnego lub z jego rozczłonkowaniem i podwojeniem pozycji syntaktycznej. Została zbadana regularność realizacji każdej formy gramatycznej w systemie trzech języków. Wnioski są oparte na danych kwantytatywnych.

Keywords: semantic syntax; explicative syntax; valence of verb; contrastive linguistics; mental verbs; Bulgarian language; Polish language; Russian language

Słowa kluczowe: składnia semantyczna; składnia eksplikacyjna; walencja czasownika; lingwistyka kontrastywna; czasowniki mentalne; język bułgarski; język polski; język rosyjski

\footnotetext{
Aleksander Kiklewicz, University of Warmia and Mazury in Olsztyn

ORCID: https://orcid.org/0000-0002-6140-6368

Correspondence: akiklewicz@gmail.com

This article was funded by the National Science Centre, Poland (NCN, Grant No. 2013/11/B/HS2/03116) as part of the research project "Syntactic properties of verbs as a basis of their integrated lexicographic description (in a Polish-Bulgarian-Russian contrastive perspective)" (2014-2017).
}

Competing interests: The author declares that he has no competing interests. 